Jacek PIENIĄŻEK ${ }^{1}$

Łukasz ZAJACZCKOWSKI ${ }^{2}$

\title{
ZAUTOMATYZOWANE STANOWISKO DO BADANIA PRZETWORNIKÓW CIŚNIENIA Z UWZGLĘDNIENIEM TEMPERATURY
}

\begin{abstract}
W artykule zaprezentowane zostało rozwiązanie techniczne systemu pomiarowego przeznaczonego do wzorcowania przetworników ciśnień. Wykonany system pomiarowy jest złożony z urządzeń pomiarowych objętych centralnym sterowaniem realizowanym przez aplikację zrealizowana w LabView. Istotnym elementem systemu umożliwiającym badanie przetwornika ciśnienia w różnych temperaturach jest miniaturowa komora termiczna, której zastosowanie stanowi alternatywę dla dużej termokomory. Zaletą programowego sterowania eksperymentem pomiarowym dostarczającym dane do kalibracji przetwornika jest pełna automatyzacja czasochłonnego procesu zbierania danych i sterowania wartościami dwu wielkości (ciśnienia i temperatury) w wielu punktach pomiarowych.
\end{abstract}

Słowa kluczowe: system pomiarowy, kompensacja temperaturowa, wzorcowanie przetwornika ciśnienia, programowanie w LabView

\section{Wprowadzenie}

Dokładność pozyskiwanych wartości zmiennych stanu opisujących lot samolotu jest krytyczna dla poprawności realizacji operacji lotniczych oraz wpływa na bezpieczeństwo lotów. Dokładność pomiaru ogranicza możliwość określenia rzeczywistego zachowania się obiektu, którego stan jest mierzony. To oznacza, że podczas sterowania z wykorzystaniem niedokładnej wartości wielkości sterowanej konieczne jest zachowanie marginesu bezpieczeństwa, często także ograniczenia szybkości reakcji układu sterującego. Dokładność pomiaru jest szczególnie krytyczna w zadaniach identyfikacji modelu obiektu, kiedy błędy pomiaru skutkują nieprawidłową informacją o zachowaniu się badanego obiektu.

Poprawność działania układów pomiarowych jest określona przez uzyskiwaną dokładność pomiaru. Stąd konieczne jest uwzględnienie w procesie projektowania urządzeń pomiarowych takich czynników jak temperatura, ciśnienie,

1 Autor do korespondencji: Jacek Pieniążek, Politechnika Rzeszowska, al. Powstańców Warszawy 12, 35-959 Rzeszów, tel. 17865 1783, e-mail: jp@ @rz.edu.pl

${ }^{2}$ Łukasz Zajączkowski, e- mail: lukaszzajaczkowski@interia.pl 
wilgotność, stałe i zmienne przyspieszenie oraz różnego rodzaju oddziaływania elektromagnetyczne, które wpływając na układ pomiarowy powodują błędy dodatkowe. Ogólnie największy wpływ na dokładność pomiaru ma przetwornik pierwotny i zwykle ten element nie tylko reaguje na wartość mierzoną, ale jest także wrażliwy na temperaturę. Redukcja błędu temperaturowego jest możliwa poprzez wykonanie kompensacji temperaturowej. Stosuje się dwie odmiany, kompensacja układowa i programowa, lecz osiągnięcie wysokiej dokładności w szerokim zakresie warunków środowiskowych umożliwia jedynie kompensacja programowa, gdyż daje możliwość uwzględnienia pełnej charakterystyki przetwornika, w tym nieliniowości i wpływu temperatury.

Realizacja kompensacji temperaturowej wymaga rozbudowania procesu wzorcowania przetwornika. Typowe wzorcowanie przeprowadzane jest w laboratorium metrologicznym w ustalonych warunkach klimatycznych, gdy często urządzenia pomiarowe, zwłaszcza takie, które dostarczają sygnałów dla systemów sterowania, pracują w szerszym zakresie warunków otoczenia [10]. Stąd w procesie wzorcowania przetworników pojawia się konieczność badania wpływu różnych czynników zakłócających, z których najważniejszym jest temperatura. Na przykład, aby lotniczy układ pomiarowy spełnił wymagania normy DO-160 [11] czyli prawidłowo pracował w warunkach wynikających ze strefy $\mathrm{w}$ jakiej jest instalowany, to na etapie projektowania konieczne jest poznanie wpływu zakłóceń obejmujących zarówno czynniki środowiskowe (temperatura, wilgotność, ciśnienie) jak i wpływ przyspieszeń stałych i zmiennych oraz różnego rodzaju oddziaływań elektromagnetycznych na elementy urządzenia. $\mathrm{Na}$ tej podstawie można zastosować rozwiązania takie jak poprane zaprojektowanie układów elektronicznych i ich topografii oraz obudowanie, które zredukują efekt zakłóceń do akceptowalnego poziomu.

Poznanie rzeczywistych charakterystyk przetworników pomiarowych pierwotnych może posłużyć do znacznej poprawy jakości pomiaru. Znając to jak przetwornik reaguje na zakłócenie możliwa jest kompensacja wpływu tego zakłócenia $[4,5]$. Na rysunku 1 przedstawiono ogólną strukturę układu programowej kompensacji temperatury, w którym na etapie przetwarzania sygnałów wykonywana jest kompensacja temperatury przy wykorzystaniu odwrotnej charakterystyki przetwornika pomiarowego. Jednak, aby poznać charakterystyki przetwornika pomiarowego konieczne jest wykonanie badań, które dostarczą informacji niezbędnych do aproksymacji rzeczywistej charakterystyki. Zastosowanie aproksymacji wynika z rzeczywistych charakterystyk zarówno samego przetwornika jak i stanowiska do wzorcowania. Ze względu na szumy sygnałów pomiarowych, zmienność wartości wielkości mierzonej i zakłóceń występujące w warunkach rzeczywistych konieczne jest uśrednienie uzyskiwanych wyników.

Metody aproksymacji obejmujące zarówno klasyczne dopasowanie funkcji o danej postaci [8] jak i metody sztucznej inteligencji takie jak system logiki rozmytej typu Takagi-Sugeno [3] czy sieci neuronowe [1] nie będą omawiane 
w niniejszym artykule. Zwrócimy jedynie uwagę, że opisywany system pomiarowy służy do dostarczenia danych do realizacji wymienionych algorytmów. Pozyskane w taki sposób wyniki pomiarów wykorzystano w opracowaniu dotyczącym zastosowania uczenia w układzie pomiarowym [7].

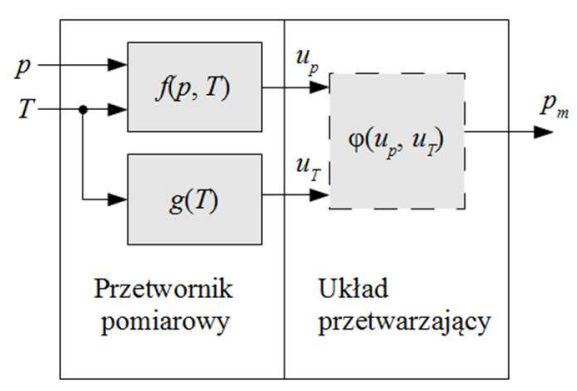

Rys. 1. Układ pomiarowy ciśnienia z programową kompensacją temperatury, $f$ funkcja przetwarzania (charakterystyka) przetwornika ciśnienia, $g$ - charakterystyka przetwornika temperatury, $\varphi$ - charakterystyka odwrotna przetwornika

Fig. 1. Pressure measurement system with software temperature compensation, $f$ - pressure sensor function, $g$ - temperature sensor function, $\varphi$ - inverse pressure sensor function

\section{Kompensacja temperaturowa przetwornika ciśnienia}

Zróżnicowanie wymagań dotyczących przetworników ciśnień wykorzystywanych w różnych układach pomiarowych jest przyczyną istnienia w ofercie przetworników znacznie różniących się pod względem dokładności. Dokładne badanie charakterystyk jest wymagane w takich zadaniach jak pomiary aerometryczne stosowane w lotnictwie (np. pomiar wysokości ciśnieniowej, pomiar prędkości lotu) oraz badaniach różnych przepływów (np. pomiar aerodynamiczny kątów opływu). Osiągnięcie dokładności odpowiadającej klasie 0.1, i lepszej, wymaga uwzględnienia pełnej charakterystyki przetwornika. Natomiast wzorcowanie przetworników klasy 1 można zrealizować z wystarczającą dokładnością metodą dwupunktową. Na sygnał wyjściowy przetwornika wpływają następujące czynniki:

- nieliniowość charakterystyki odpowiedzi na sygnał mierzony $(p)$,

- zmiany charakterystyki pod wpływem temperatury, które w ograniczonym zakresie opisuje się jako zmianę czułości i przesunięcie charakterystyki (zera),

- wpływ innych zewnętrznych czynników zakłócających (np. przyspieszenie stałe, wibracje),

- wpływ czynników wewnętrznych jak zakłócenia zasilania przetwornika czy zakłócenia elektromagnetyczne,

- zależność poziomu szumu w sygnale od warunków - typowo szum narasta wraz ze wzrostem temperatury, 
- histereza - czyli różne odkształcenia elementu pomiarowego a wskutek tego różne wskazania w zależności od znaku zmiany ciśnienia,

- histereza temperaturowa - zmieniająca się charakterystyka przetwornika w wyniku przejścia cyklu zmian temperatury,

- stabilność wskazań (krótkookresowa i długookresowa).

Funkcja przetwarzania przetwornika (1) uwzględnia jawnie dwa pierwsze czynniki.

$$
u_{p}=f(p, T)
$$

Inne zakłócenia (jak stałe przyspieszenie) można także ująć w funkcji (1) jako dodatkową zmienną. Pewne czynniki będą miały wpływ (np. drgania) na zwiększenie poziomu szumu na wyjściu przetwornika. Zakłócenia wewnętrzne powinny być zredukowane w rozwiązaniu konstrukcyjnym przetwornika i układu pomiarowego. Natomiast histereza oraz stabilność krótkookresowa limitują dokładność pomiarów wykonywanych określonym przetwornikiem. Charakterystykę odwrotna przetwornika opisują wzory (2) lub (3).

$$
\begin{aligned}
& p=\varphi\left(u_{p}, T\right) \\
& p=\varphi\left(u_{p}, u_{T}\right)
\end{aligned}
$$

Wynik pomiaru jest wyliczany na podstawie sygnału uzyskiwanego z przetwornika i informacji o wielkości zakłócenia (tu jako temperatura lub sygnał wyjściowy z czujnika temperatury - zależnie od sposobu wzorcowania). Istnienie jednoznacznego odwzorowania odwrotnego warunkuje możliwość kompensacji wpływu zakłócenia.

Metody kompensacji wpływu temperatury można podzielić na dwie grupy: kompensację układową oraz kompensację programową. Pierwsza metoda polega na tym, że w układzie elektronicznym przetwornika umieszcza się element, którego wpływ na sygnał wyjściowy spowodowany zakłóceniem ma przeciwny znak w porównaniu do oddziaływania za przetwornik. Ze względu na ograniczoną możliwość kształtowania charakterystyk takich elementów kompensacja sprzętowa redukuje błąd do pewnego poziomu. Stąd przetworniki ciśnień skompensowane w układzie cechują się lepszymi parametrami od nieskompensowanych lecz nadal wpływ temperatury jest na takim poziomie, że zmiany temperatury o ok. $10^{\circ} \mathrm{C}$ powodują błąd ponad $0.1 \%$ zakresu przetwornika $[6,9]$.

Kompensacja programowa polega na wprowadzeniu zależności (2) lub (3) w oprogramowaniu układu pomiarowego. Aby jednak było możliwe wprowadzenie tej zależności konieczne jest wykonanie badania przetwornika, które dostarczy dane dla aproksymacji poszukiwanej funkcji. 
Dla zobrazowania redukcji błędu, która jest osiągalna po przeprowadzeniu wzorcowania z kompensacją programową zostaną zaprezentowane wyniki badania przetwornika ciśnienia absolutnego dla wysokościomierza barometrycznego (zakres $1100 \mathrm{hPa}$ ). Charakterystykę przetwornika obrazuje wykres powierzchni aproksymującej punkty zebrane podczas wzorcowania podany na rys. 2. Widoczne jest odkształcenie charakterystyki spowodowane temperaturą.

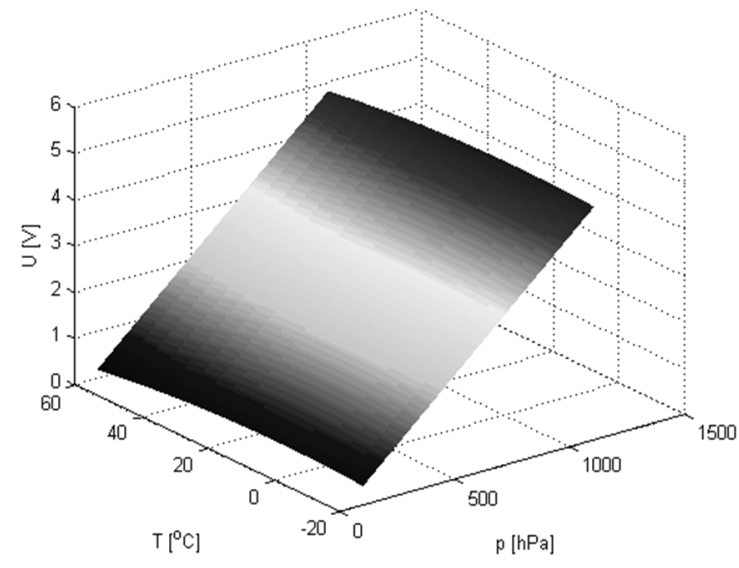

Rys. 2. Wizualizacja charakterystyki przetwornika ciśnienia

Fig. 2. The visualization of the response of the pressure transducer

Dla oceny ilościowej wykorzystane zostało odchylenia standardowego $\sigma$ liczonego według zależności (4).

$$
\sigma=\sqrt{\frac{1}{N} \sum_{\substack{\left.p, u_{p}, u_{T}\right)_{k} \\ k=1 . . N}}\left(\varphi\left(u_{p}, u_{T}\right)-p\right)^{2}}
$$

W zależności (4) $\hat{\varphi}$ jest aproksymacją charakterystyki przetwornika, $N$ jest liczbą punktów w jakich liczone są błędy odwzorowania charakterystyki, $\left(p_{r}, u_{p}, u_{T}\right)_{k}$ - jest punktem pomiarowym zawierającym wartość rzeczywistą ciśnienia, napięcie wyjściowe $\mathrm{z}$ przetwornika ciśnienia i napięcie wyjściowe $\mathrm{z}$ przetwornika temperatury.

Wartości $\sigma$ umieszczone w tabeli 1 dla różnych sposobów aproksymacji (wielomiany odpowiednich stopni oraz system rozmyty) pokazują konieczność uwzględnienia temperatury podczas skalowania. Ważne jest także przeprowadzenie pomiarów w wielu punktach, aby odwzorować nieliniowość rzeczywistej charakterystyki. 
Tabela 1. Odchylenia standardowe błędu w zależności od rodzaju aproksymacji

Table 1. Standard deviations of the error depending on the type of approximation

\begin{tabular}{|l|c|c|c|c|c|c|}
\hline \multirow{2}{*}{ Rząd wielomianu } & Bez T & \multicolumn{4}{|l|}{ Wielomiany z uwzględnieniem T } & \multirow{2}{*}{ Takagi-Sugeno } \\
\cline { 2 - 6 } & $\mathrm{n}=1$ & $\mathrm{n}=1$ & $\mathrm{n}=2$ & $\mathrm{n}=3$ & $\mathrm{n}=4$ & \\
\hline$\sigma, \mathrm{hPa}$ & 2.1 & 0.73 & 0.41 & 0.12 & 0.091 & 0.090 \\
\hline
\end{tabular}

\section{System pomiarowy do badania przetworników}

Badanie przetwornika $\mathrm{z}$ uwzględnieniem wpływu temperatury wymaga utworzenia stanowiska, w którym będzie możliwość sterowania zarówno wielkością mierzoną (czyli ciśnieniem) jak i temperaturą przetwornika. Możliwe są dwa rozwiązania:

- umieszczenie przetwornika w komorze termicznej i sterowanie ciśnieniem,

- umieszczenie przetwornika w termobarokomorze i sterowanie obydwoma wielkościami.

Drugie rozwiązanie jest limitowane stabilnością utrzymywania ciśnienia przez termobarokomorę. $\mathrm{Z}$ tego powodu w badaniach [2], mimo zastosowania termobarokomory, sterowanie ciśnieniem dostarczanym do przetworników odbywało się z zewnętrznego kalibratora. Istotną wadą zastosowania dużej komory jest wprowadzenie znaczącej pojemności cieplnej. Skutkuje to długimi czasami osiągnięcia stanu ustalonego i wymaganiem dużej mocy układów chłodzenia i grzania. W pierwszym z rozwiązań wielkość komory można znacząco zredukować. Proponuje się rozwiązanie polegające na utworzeniu stanowiska, którego ideę zaprezentowano na rysunku 3. Sterowanie wartości temperatury odbywa się poprzez sterowanie prądem zasilającym moduł Peltiera. Przetwornik temperatury dostarcza sygnał sprzężenia zwrotnego dla układu sterowania temperaturą oraz informacje o aktualnej temperaturze badanego przetwornika.

Odprowadzanie ciepła rozwiązano poprzez zastosowanie zbiornika ciepła, do którego moduł Peltiera przekazuje energię w trakcie chłodzenia i z którego pobiera ją (częściowo) w trakcie ogrzewania badanego przetwornika. Pozostałe elementy systemu pomiarowego to:

- kalibrator ciśnień (sterownik ciśnienia), który służy do sterowania ciśnieniem lub ciśnieniami (zależnie od rodzaju przetwornika) oraz realizuje pomiar wzorcowy zadawanego ciśnienia,

- moduł akwizycji danych (DAQ), który służy do pomiaru sygnałów napięciowych (pomiar temperatury),

- woltomierz (multimetr), którym mierzone jest napięcie wyjściowe z przetwornika ciśnienia. 


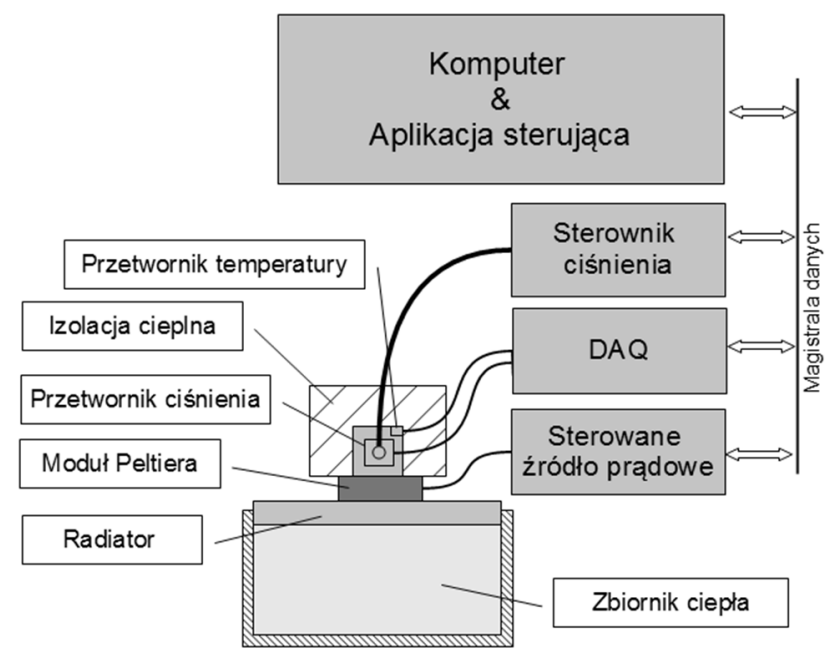

Rys. 3. Struktura stanowiska pomiarowego do wzorcowania przetworników ciśnień

Fig. 3. Structure of the measurement stand for pressure transducer calibration

Zastosowana tu wersja oprogramowania stanowiska umożliwia współpracę z kalibratorem PACE6000, multimetrem 34410A i kartą pomiarową NI-USB 6216 (lub inną zgodną ze sterownikiem NI-DAQmx). Dodatkowo, ze względu na konieczność zmiany polaryzacji prądu zasilającego moduł Peltiera jedno z wyjść binarnych karty zostało wykorzystane do sterowania przekaźnikiem zmieniającym polaryzację zasilania. Na rysunku 4 widoczne są rozkłady temperatur i obraz termiczny przetwornika ciśnienia (przecięcie linii) umieszczonego w bloku izotermicznym (ciemny kwadrat - temperatura ok. $-15^{\circ} \mathrm{C}$ ) izolowanym (w przekroju A temperatura izolacji ponad $20^{\circ} \mathrm{C}$ ) i chłodzonym od dołu przez moduł Peltiera. Widoczne nierównomierności temperatury są to fragmenty pasty termoprzewodzącej, która wobec zdjęcia izolacji czołowej ma wyższą temperaturę niż blok izotermiczny i sam przetwornik. Pomiar temperatury przetwornika należy realizować tak jak w urządzeniu docelowym co powoduje, że na dokładność kompensacji ma wpływ jedynie stabilność przetwornika temperatury.

Celem eksperymentu jest uzyskanie informację niezbędnej do aproksymacji funkcji odtwarzającej przetwornika. To powoduje konieczność przeprowadzenia badania $\mathrm{w}$ przedziale eksploatacyjnego zakresu temperatur i przedziale mierzonych ciśnień. Zagęszczanie siatki punktów pomiarowych w planie eksperymentu umożliwia zwiększenie dokładności odtworzenia funkcji $\varphi$, lecz wiąże się z wydłużeniem czasu realizacji badania. Dotyczy zwłaszcza badania wpływu temperatury ze względu na stosunkowo długi czas osiągania stanu ustalonego. 
Mimo zastosowania komory termicznej o małej pojemności cieplnej każda zmiana temperatury wprowadza w eksperymencie co najmniej kilkuminutową przerwę w zbieraniu danych (czas ustalania się temperatury widać na rysunku 6 w [7], gdzie w badaniach wykorzystano komorę opisywaną w rozdz. 3 a cały proces zbierania danych trwał ok. 6 godzin).

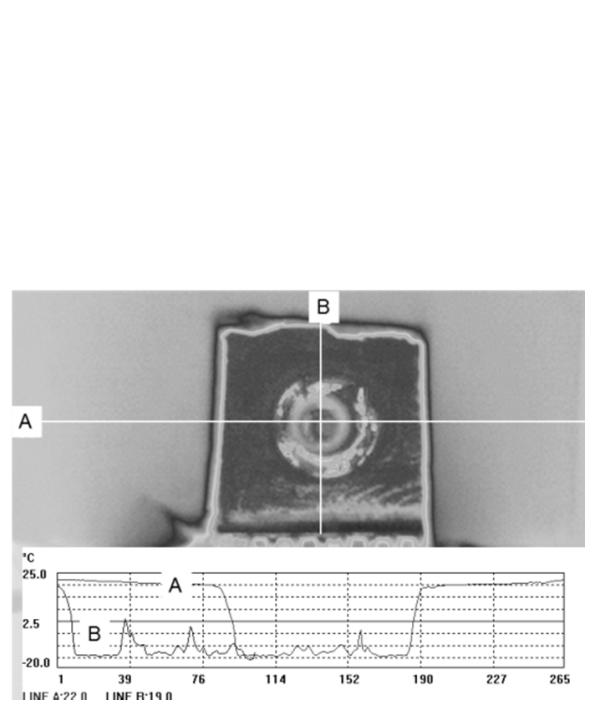

Rys. 4. Obraz termiczny komory

Fig. 4. Thermal image of chamber

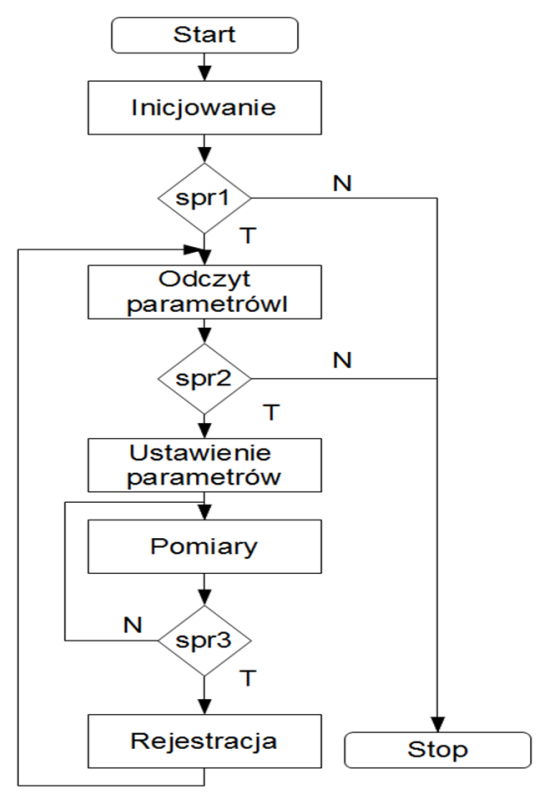

Rys. 5. Algorytm sterowania procesem pomiarowym

Fig. 5. Algorithm controlling the measurement process

Algorytm działania programu zaprezentowano na rys. 5. Po zainicjowaniu wszystkich urządzeń, o ile inicjowanie zakończyło się sukcesem (spr1), rozpoczyna pracę główna pętla programu. W kolejnych cyklach po odczycie parametrów zadanych w planie badania bądź wprowadzonych przez użytkownika system steruje temperaturą i ciśnieniem aż do osiągnięcia wartości żądanych parametrów (spr2). Po stwierdzeniu ustalenia się wartości temperatury i ciśnienia (spr3) następuje rejestracja wyników pomiaru i rozpoczyna się kolejny cykl.

Proces rejestracji uwzględnia występowanie zakłóceń o charakterze losowym. Redukcję zniekształceń spowodowanych wpływem szumu uzyskuje się poprzez wielokrotny pomiar $\mathrm{w}$ stanie ustalonym $\mathrm{i}$ wykorzystanie uśrednionej wartości jako punktu charakterystyki. 


\section{Oprogramowanie systemu pomiarowego}

Oprogramowanie systemu pomiarowego można realizować z zastosowaniem różnych narzędzi od języków ogólnego przeznaczenia do specjalizowanych narzędzi programistycznych jakim jest środowisko LabView zastosowane w niniejszej aplikacji. Oprogramowanie składa się z dwu części:

- interfejsu użytkownika,

- algorytmu działania.

Interfejs użytkownika został zaprezentowany na rysunku 6 . W bloku sterującym zawiera elementy, które służą do określenia parametrów dla urządzeń stanowiska pomiarowego oraz parametrów procesu sterowania eksperymentem. Dodatkowo wprowadzone zostały elementy prezentujące stan procesu pomiarowego w formie wykresów i tabeli wyników.

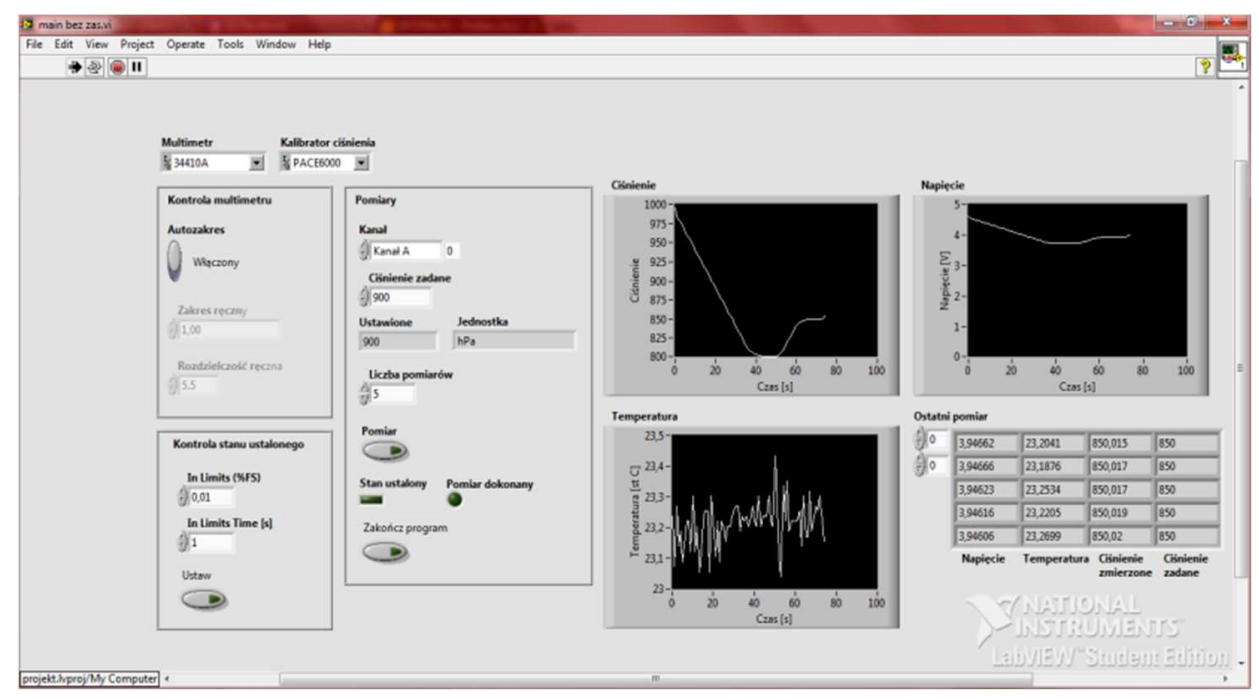

Rys. 6. Interfejs programu sterującego eksperymentem pomiarowym

Fig. 6. Interface of the software controlling the measurement experiment

Na rysunkach 7 oraz 8 zaprezentowane zostały fragmenty kodu programu, utworzonego w graficznym języku G. Idea tego sposobu programowania wynika z przyjęcia zasady sterowania praca programu zgodnie z przepływem danych oraz tworzeniu oprogramowania metodą graficzną. Widoczne fragmenty są to kody wywoływane warunkowo. Fragment programu będącego realizacją funkcji pomiaru i detekcji stanu ustalonego (rys. 7) analizuje wyniki pomiaru aż do stwierdzenia osiągnięcia stanu ustalonego. Następnie następuje przełączenie konfiguracji na tryb pomiaru i rejestracji (rys. 8), w którym to trybie w pętli zbierane są wyniki. Następnie po uśrednieniu wartości poszczególnych sygna- 
łów są rejestrowane jako jeden punkt pomiarowy. Zapis jest powtarzany w zależności od ustawionej liczby próbek.

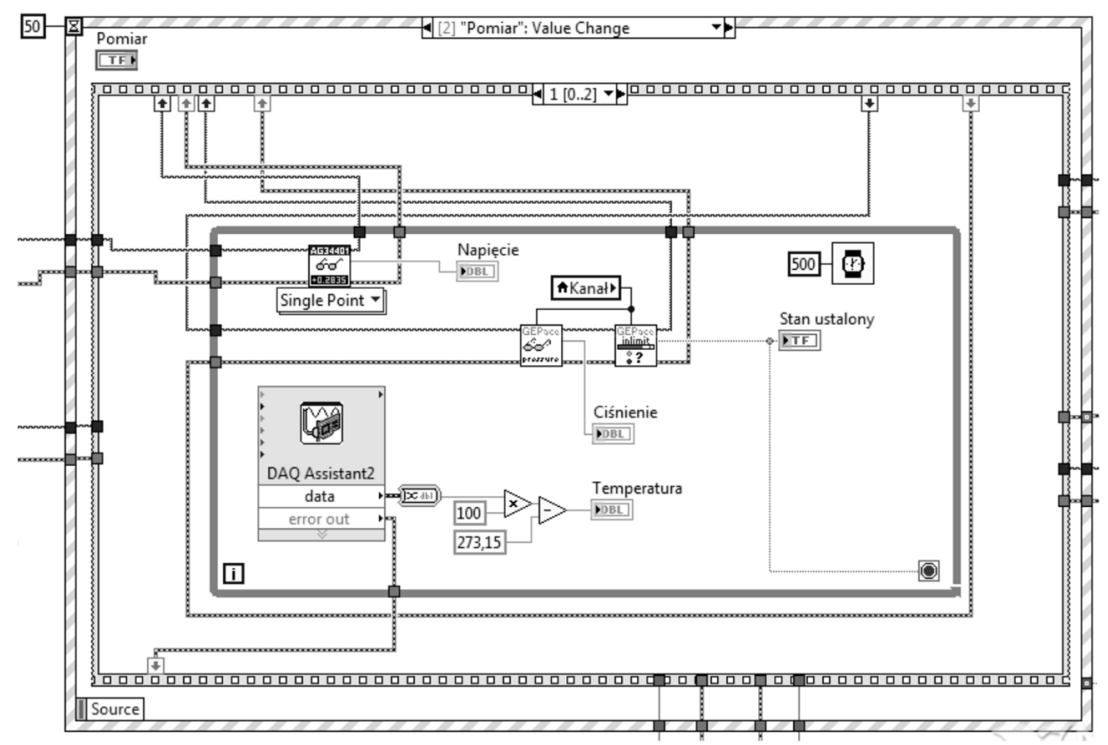

Rys. 7. Fragment programu wykonujący pomiary i wykrywający stan ustalony

Fig. 7. Fragment of program realized measurement and detection of the steady state condition

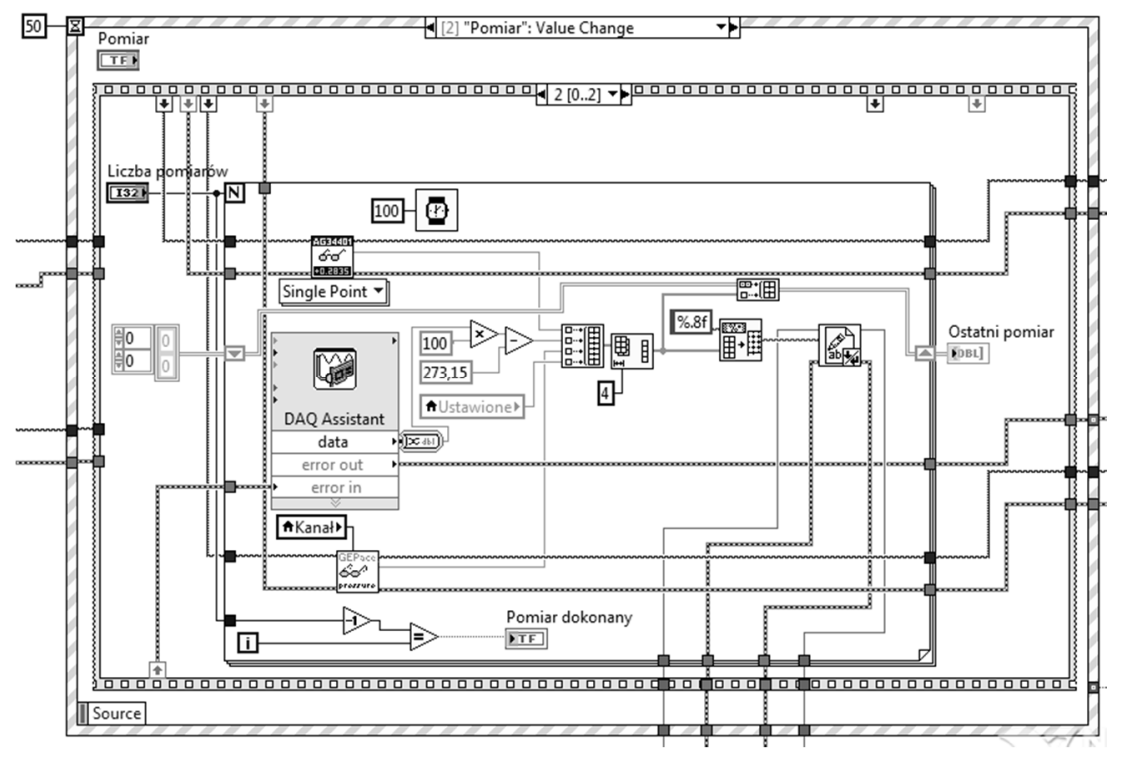

Rys. 8. Fragment programu wykonujący pomiary i rejestrujący wyniki

Fig. 8. Fragment of program realized measurement and recording results 


\section{Podsumowanie}

Artykuł prezentuje rozwiązanie techniczne zadania pomiarowego dotyczącego wzorcowania przetwornika ciśnienia. Uzasadnieniem wzorcowania z uwzględnieniem wpływu temperatury jest możliwość znacznej redukcji błędu pomiaru, ponad dziesięciokrotnie $\mathrm{w}$ porównaniu $\mathrm{z}$ wzorcowaniem $\mathrm{w}$ jednej temperaturze, jeśli przetwornik przeznaczony jest do pracy w warunkach braku stabilizacji termicznej. Opisana aplikacja umożliwia zautomatyzowanie czasochłonnego procesu zbierania danych co w efekcie redukuje nakład pracy człowieka. Natomiast zaproponowane rozwiązanie układu sterowania temperaturą badanego przetwornika jest stosunkowo tanią alternatywą dla komór termicznych, charakteryzując się dodatkowo mniejszą bezwładnością cieplną.

Należy zwrócić uwagę, że liczba punktów pomiarowych w planie eksperymentu wpływa na błędy odwzorowania charakterystyki danego przetwornika. Wynikowa dokładność wzorcowania jest uwarunkowana klasą zastosowanych narzędzi pomiarowych; tu krytyczna jest dokładność kalibratora ciśnień.

\section{Literatura}

[1] Arpaia P., Daponte P., Grimaldi D., Michaeli L.: ANN-based error reduction for experimentally modeled sensors, IEEE Trans. Instrum. Measurement, 51 (2002) 23-30.

[2] Ciecinski P., Nowak D., Pieniazek J., Walek L.: Integrated measurement system for UAV, Metrology for Aerospace (MetroAeroSpace), IEEE Xplore, 2015, pp. 446$-451$.

[3] Depari A., Flammini A., Marioli D., Taroni A.: Application of an ANFIS Algorithm to Sensor Data Processing, IEEE Trans. Instrum. Measurement, 56 (2007) 75-79.

[4] Fraden J.: Handbook of Modern Sensors, 4th edition, Springer, 2010.

[5] van der Horn G., Huijsing J. L.: Integrated Smart Sensors, Design and Calibration, Springer Science, Business Media Dordrecht 1998.

[6] Lee B., Kim K., Park H., Shin S., Calibration and temperature compensation of silicon pressure sensors using ion-implanted trimming resistors, Sensors Actuators, A72 (1999) 148-152.

[7] Pieniążek J., Cieciński P.: Measurement device with learned sensor, Metrology for Aerospace (MetroAeroSpace), IEEE Xplore, 2014, pp. 260-264.

[8] Soderstrom T., Stoica P.: System Identification, Prentice Hall, London, 1989.

[9] Zajączkowski Ł.: Sterowanie systemem pomiarowym z wykorzystaniem środowiska LabVIEW, praca inżynierska, WBMiL, Politechnika Rzeszowska, 2014.

[10]Wang Q., Ding J., Wang W.: Fabrication and temperature coefficient compensation technology of low cost high temperature pressure sensor, Sensors Actuators, A 120 (2005) 468-473.

[11]DO-160G Environmental Conditions and Test Procedures for Airborne Equipment, RTCA, 2010. 


\section{AUTOMATED STAND FOR TESTING PRESSURE TRANSDUCES \\ INCLUDING TEMPERATURE EFFECT}

\section{S u m m a r y}

This paper presents the technical solution of the measurement system for pressure transducers calibration. The system consists of measurement devices which are controlled by the software developed in LabView. An essential component of the system enabling investigation of the transducer in different temperature is a miniature thermal chamber which was designed as alternative to the large thermal chamber. The advantage of software control of measuring experiment supplied data for calibration of transducer is fully automation of the time-consuming process of data acquisition and controlling the values of pressure and temperature in many measuring points.

Keywords: measurement system, temperature compensation, pressure transducer calibration, LabView programming

DOI: $10.7862 / \mathrm{rm} .2017 .08$

Otrzymano/received: 25.11 .2016

Zaakceptowano/accepted: 23.02.2017 